\title{
Information Design and Infography contributions to enhance audiologists through digital educational material
}

Camila Medina,

Tacianne Kriscia Machado,

Regina Tangerino de Souza Jacob,

Cassia Leticia Carrara Domiciano

\section{INTRODUCTION}

The Frequency Modulation System (FM) is an educational tool developed for children with hearing impairments, users of hearing aids and/or cochlear implants, which aims to improve the comprehension of the speech signal in noisy environments, reverberating and the distance between the individual and the sound source, mainly in the school environment (Blasaca, Ferrari and Jacob, 2006; Queiroz-Zattoni, 2011; Jacob et al, 2012). It is a feature of assistive technology consisting of two parts: transmitter and receiver. In the school routine, the transmitter captures the teacher's voice through a microphone and leads it to the receiver - device installed next to the student's hearing aid. Its goal is to improve communication among the hearing loss, teachers, colleagues and family members. (Brazil, 2015; Alves, 2016).

It is understood by assistive technology, according to the Technical Aid Committee (CAT, 2009, p. 9), products, resources, methodologies, strategies, practices, and services that promote autonomy, independence, quality of life and social inclusion of people with disabilities or reduced mobility.

For years, the inclusion of the FM System in regular classrooms benefits children with hearing impairment. However, its use became more accessible through the incorporation of the FM System to the Brazilian National Health System (SUS), which occurred from the publication of the Decree 1,274, from 25 June 2013, which includes the FM System in the Table of Procedures, Medicines, Orthotics, Prostheses and Special Materials (OPM) (Brazil, 2013). Since its implantation until December 2017, SUS has made available around 8,914 devices for the population. Because it is a device considered high cost, training actions that favor its proper use and avoid the abandonment or disinterest on the part of 
the user in using this tool are essential to avoid problems for public health.

For the proper implementation of a Program of Concession, Adaptation, and Monitoring of the FM System in students with hearing impairment in Brazilian schools it is necessary an intersectoral work, characterized by a careful articulation between the Education and Health Systems. Network actions must integrate the different levels of attention of the person with hearing loss, as the inter-ministerial policy Live Without Limits. (SDH-PR/SNPD, 2013)

The training of the professional active in Auditory Health Services, as to the use of the equipment is of fundamental importance, as well as its constant improvement. Just so all the recommendations proposed by the Ministries of Health and Education can be gradually deployed and the student with hearing loss can have the practical benefit with this type of assistive technology.

In Brazil, because of the sizeable territorial extension and, mainly, due to the differences in vocational training, the need to create educational programs in the area of health becomes increasingly necessary (Ferrari et al., 2010). In this direction, the design can, in different aspects, contribute to a more effective educational action in health, through the development, in multidisciplinary teams, of educational materials and various informative.

Lopes, Coutinho and Barbosa (2012) concluded in his study about the contribution of design methodologies to the Pedagogical Practice that there is a need to broaden and strengthen the research that articulates intervention processes of basic educational design and with non-specialists in the area. The methodological arguments of the Information Design (ID) are the most appropriate for such processes, as they present a "systematic, organizational and prospective vision" (Coutinho and Freire, apud Lopes, Coutinho and Barbosa, 2012). Still, according to the same authors, Information Design's assignments help with the identification of problems, on evaluation and analysis of usage situations, and on the consequent improvement of information systems in general.

Therefore, actions in design in the organization and information structuring and the process of conception, planning and evaluating of such educational tools, as well as the performance of multidisciplinary team focused on the needs of users are indispensable (Fassina, Cavalcante and Andrade, 2009; Oliveira, Coutinho and Campello, 2013).

It is the area of the Information Design that houses these actions in design and education, guided by the effective communication of varied content to users also diverse. This is why the Information Design is focused on this article, which presents the development of a website, the FM System Portal, available at the electronic address www.portalsistemafm.fob.usp.br. By the use of Interactive Teleducation and the Internet, it is possible to offer updates on the technology hi- 
ghlighted here, reaching professionals distributed throughout the country.

It is noteworthy that this work has originated from a master's research conducted in the Audiology Department Bauru School of Dentistry, University of São Paulo (Alves, 2016). Recently, a translated and transcultural adapted version of English language was incorporated into the portal, with multi-disciplinary validation of six units available at the portal for greater coverage of the content (Guedes, 2017).

The planning and design of this portal were carried out with the help of the Educational and Computer Technology Sectors of the same institution. In this way, this project featured a team composed of professionals from the areas of Audiology, Design and IT.

After development, the material was evaluated by professionals in Audiology area, using a Motivational Research Form (FPM), in order to verify the effectiveness of this virtual environment of transmission of information on FM System using the Interactive Teleducation.

\section{INFORMATION DESIGN AND INFOGRAPHY ON EDUCATIONAL ACTIONS}

The Information Design is a projective activity that seeks the conceptual understanding among elements and their meanings and relationships, transposing the structuring and agglutination of information through the relationships among content, visual communication, and language. It acts as a facilitator in the selection, structuring, and organization of information in complex systems. "It is responsible for outlining the way in which the user finds the information, performs its reading, establishes the relationship among its elements, interacts with the interface and understands this experience" (Passos and Moura, 2007, p. 22).

Rodrigues (2016) points out that the Information Design, along with the Web Design, and the Information Sciences, has the ability to "power the enhancement and conception of informational artifacts." There are also the questions related to the architecture of information, usability, and concern with the visualization of the information. The information design, however, encompasses issues not only related to the digital products referred by the author, but to any communication and reading artifacts that measure the relationships between the information and its user.

Pena de Sá $(2016)^{1}$ Organized, through a bibliographical survey, the princi-

1 Adapted from Petterson (2012), O'Grady e O'Grady (2008), Lidwell et al. (2010), Rogers et al. (2013) e Garcia (2012).: 
ples of the Information Design in four groups. Below it is categorized some of these factors pertaining to the project in question.

1 Communication: organize, categorize, prioritize, customize, and differentiate information from a publication. Some of the principles are:

- LATCH: organization of content according to five topics: Local, Alphabet, Time, Category, Hierarchy;

- Modularity: administration of the complexity of systems employing functional grouping by similarity;

- Minimum Effort: preference of individuals by familiar tools, accessible, comfortable and easy to use.

2 Cognition: communicating the message in a clear, accessible and easy way to the intended audience, understanding the cognitive sciences in order to substantiate aesthetic decisions in the process of creating the graphics project. Its fundamentals are:

- Learning Styles: sensory method of preference of the individual that makes memorize the transmitted information, which can be visual, auditory-verbal or synesthesia-tactile;

- Principles of Gestalt perception: unity, segregation, unification, closure, proximity, similarity and pregnancy of form;

- Memory: direct it to make it easier for the information to be remembered in its entirety;

- Wayfinding (auto-orientation within an environment and cognitive processes used in choosing the route to be followed)

- - Informational overload (over-supply of incapacity to be processed, assimilated and understood by individuals).

3 Aesthetics: to provide the ease of perception through the use of design principles in visual presentation. The principles are:

- Structure: base where informational elements are organized, hierarchical and positioned;

- Readability: Features of text, image or color, which can alter visual perception;

- Proportion: Provides dynamics between the different elements in a layout;

- Harmony: a Harmonious relationship between the elements in a design. 
4 Usability: promote better experience in the use of interactive systems. Its principles are:

- Visibility: the functions must be undoubtedly visible as well as the actions to be carried out and their respective consequences);

- Feedback: the return of information through an action that allows the user to continue in their task);

- Restrictions: reduce the amount and variety of actions that can be performed on a given system);

- Consistency: when similar parts are expressed in a similar way

- Affordance: how the user interacts with the object or environment and how their properties are perceived to determine the way to be used.

The understanding and application of these principles of Information Design corroborate for the creation of graphics products aimed at the needs of the target audience that can be used in the data visualization in infography.

According to Domiciano (2017), the infography gains every day more space as a communication tool, starting from the traditional use in media, such as newspapers, magazines, and leaflets, for digital formats, also penetrating in previously thoughtless areas. Today the infographics have become strong allies in the area of teaching, both in printed and digital media. They are "visual representations of informational character, with high power of attraction, that combine text and image (photography and/or illustration) to reveal the unknown and explain the complex, in a simple, synthetic and with focus on the receiver of the message" (Fassina, Cavalcante and Andrade, 2009, p. 290). These graphic representations feature the hybridism of languages that aims to provide a more efficient understanding.

In order to be understood in its entirety, the infographics must be designed with the adequate visual presentation, according to the precepts of Graphic Design and Information Design. Moreover, when in the educational context, they illustrate complex information in a compact form, in order to allow better interpretation of concepts and ideas and benefit the retention of information (Bicen and Beheshti, 2017)

Infography operates as a complement of teaching in the context of interactivity and dynamic, modernizing the scientific text in order to make it more didactic and appropriate to the educational context that applies (Pessoa and Maia, 2012).

According to Cairo (2008, p. 16), the infography allows data, transformed into visual information, to become attractive by itself, without the need for arti- 
fice, either on a printed page or the web. Infography should act as a real analysis tool in the service of the reader. Its priority is not to generate lighter, dynamic or with impactive design pages - even if it does so many times - but to improve understanding in the first place. Still according to the author, the incorporation of interactive tools in digital publishing propels a paradigm shift in the display of information: the traditional freedom that the reader has in reading the contents of an infography in the order that he thinks best, creating meaning from the data and the digital format, with the construction of interaction made, no longer from the infography itself, but by the navigation design.

\section{THE VIRTUAL LEARNING ENVIRONMENT}

The present work was developed in the Department of Speech-Language, Pathology, and Audiology, Bauru School of Dentistry - University of São Paulo, with approval by the Committee of Ethics in Research of that University (CAAE: 38577014.0.0000.5417, Protocol No. 970.760/ 2015).

The development of the contents of the FM System Portal was based on the phases of development of instructional design proposed by Filatro and Piconez (2004), as steps below. It is emphasized that the phases proposed by the authors are produced jointly, and modifications can be made throughout the process.

\section{First Step: Analysis and planning}

The first stage involved the identification of learning needs, defining instructional objectives and lifting the restrictions involved. This stage was based on the Protocol of the American Academy of Audiology "Remote Microphone Hearing Assistance Technologies for Children and Youth from Birth to 21 years" (American Academy of Audiology, 2011)

\section{Second Step: Content development and interface design}

In this stage, the preparation of the content was carried out. The textual content has been transformed into infographics according to the principles of Graphic Design and the Information Design so that the virtual learning environment meets the wishes and needs of the users.

The main themes that should be addressed in the FM System Portal were selected for the transmission of information about the FM System to the audiologists, and the layout was developed. The site consists of seven modules:

\section{Module 1: NOISY AND SCHOOL}

2. Module 2: FM SYSTEM 
3. Module 3: ADAPTATION AND MONITORING OF THE FM SYSTEM

4. Module 4: GUIDELINES FOR PARENTS AND TEACHERS

5. Module 5: TESTIMONIALS

6. Module 6: TROUBLESHOOTING

7. Module 7: EVALUATE THE PORTAL

The design of each module in question was accomplished through methodologies in graphic design by a designer familiar to the subject. A visual identity was developed for the product, beginning with the creation of a brand for the portal, as shown in Figure 1.

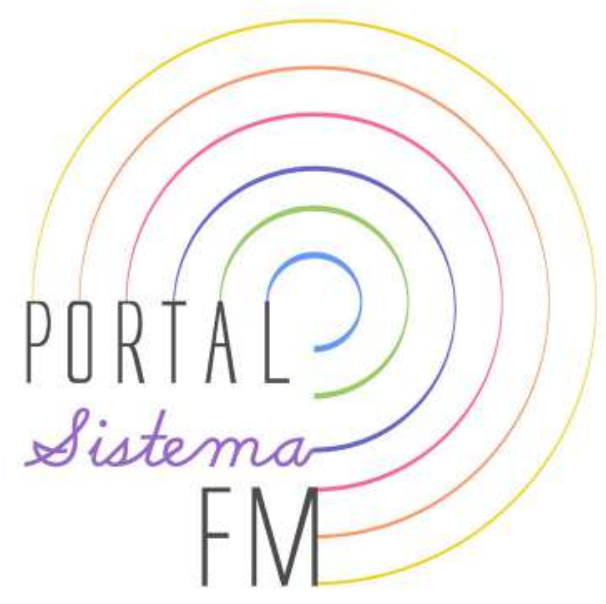

Figure 1: Brand of FM System Portal

Each module counted on the application of graphic elements coherent to the visual system created, at the same time allowing identification and differentiation among the modules. Determining a graphical composition implies understanding what type of message should be transmitted to the user by a given form. In this way, "creating a design is much more than simply assembling, formatting, or even editing; It is adding value and meaning "(Samara, 2010, p. 6). The elements were used to value the product were: photographs, illustrations, graphics, and pictograms.

Alesandrini (1984) indicates evidence that the strategy of using pictures facilitates adult learning. The illustrations of a scientific nature value the bidimensionality, and it can represent the depth by resources such as tonal variations, colors 
and textures (Trota and Spinillo apud Domiciano, 2017, p. 45), which corroborates with the graphic language chosen for the illustrations present in the portal.

Regarding the typography, two distinct sources were used - a handwritten used in titles, which refers to the school environment and another without serif, which makes easier to read in a digital environment. The set of fonts employed in a project depends on the functional nature of the content, and not only on its visual effect. Thus, to determine an identity, the choice of two families is sufficient (Samara, 2011).

It is noteworthy that, besides the brand and modules on the FM System, some instructional materials were also developed and others were made available by the companies manufacturers of the devices: video tutorials; videos with testimonials from FM System users; Tutorials for printing, containing both professional procedures, problems and solutions of the FM System; questionnaires/inventories for printing.

The visual identity developed for the portal and for the various graphic materials mentioned reduced and transformed the textual content. The graphics language adopted in this conception was of simple illustrations and several colors that refer to the child and school environment, as shown in Figures 2 a.

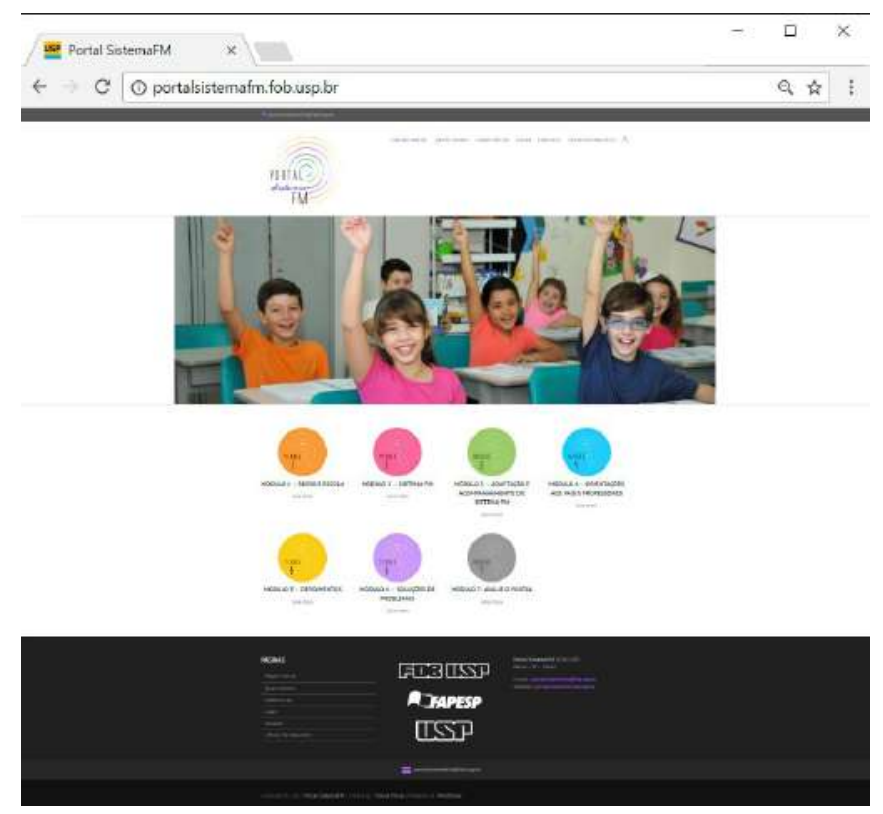

Figure 2: Home screen with the layout of the FM System Portal 

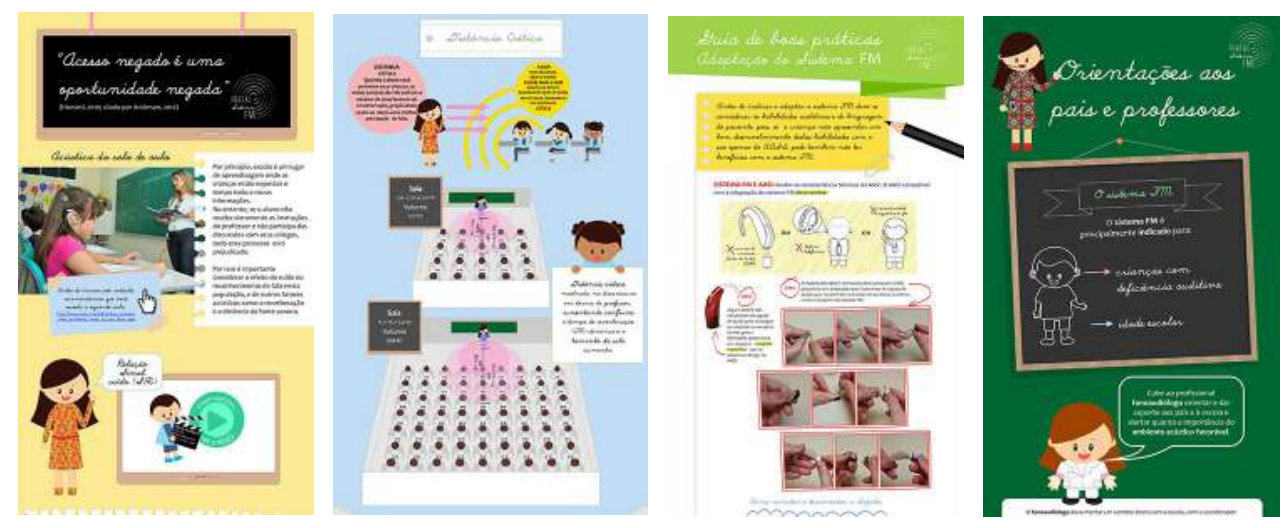

Figures 3, 4, 5 and 6: Examples of infographics used in different modules.

\section{Third Step: implementation}

It was analyzed which technological resources should be used for the proposed objective to be achieved. In this stage, the adequacy of the virtual learning environment was performed, aiming at the effective transmission of the content elaborated in the previous stages.

In the implemented products, all modules are capable of viewing in online and offline digital support or still printing, as they can be "downloaded" in PDF file by the user of the material. It also involved the monitoring, revision, and maintenance of the proposed system.

\section{MATERIAL EVALUATION}

Evaluating the efficiency of the material with the target audience was another strong point of the research presented here.

\section{Methodological Procedures}

The methodology for this is presented below, as well as the evaluations carried out.

\section{Participants}

It was invited to the research, through e-mail and social network, audiologists who acted in Auditory Health Services accredited by the Brazilian National Health System - SUS (inclusion criterion) in the five regions of the country. 
Participated voluntarily in the study, after the signing of the Term of Free and Informed Consent approved by the Ethics Committee on Research in Human Beings of the Institution, 31 audiologists:

- Age: between 23 to 62 years old (average 29,8 \pm 9,08 years), a participant did not answer;

- Experience time: Three months to 39 years of experience in the audiology area (average $4.29 \pm 7.29$ years); Two didn't answer.

- Place of Operation: Southeast regions (94\%) and South (6\%)

- Degrees: Undergraduate (49\%), specialization (19\%), Master's degree (19\%), Master's degree and specialization (3\%) and Ph.D. (10\%)

\section{Instruments}

For the evaluation of the effectiveness of the graphics project of the training program, it was used the instrument of Motivational Research Form (FPM), (Paixão, 2008; Blasca, 2012).

When completing access to the modules the form was used to subjectively assess the motivational aspects of the Training Program in fourth domains, as shown in table 1.

\begin{tabular}{|l|l|l|l|l|}
\hline QUESTIONS & $\begin{array}{l}3= \\
\text { strongly } \\
\text { agree }\end{array}$ & $\begin{array}{l}2= \\
\text { somewhat } \\
\text { agree }\end{array}$ & $\begin{array}{l}1= \\
\text { somewhat } \\
\text { disagree }\end{array}$ & $\begin{array}{l}0= \\
\text { strongly } \\
\text { disagree }\end{array}$ \\
\hline $\begin{array}{l}1 \text { The screen layout of this course is } \\
\text { attractive. }\end{array}$ & & & & \\
\hline $\begin{array}{l}2 \text { There is a menu or of sitemap } \\
\text { the beginning that describes what } \\
\text { content is contained within the } \\
\text { course. }\end{array}$ & & & & \\
\hline $\begin{array}{l}3 \text { Audiovisual information included } \\
\text { in this course helps to clarify or } \\
\text { describe the course content. }\end{array}$ & & & & \\
\hline $\begin{array}{l}4 \text { Navigating this course does } \\
\text { not require any unique skills or } \\
\text { experience by me. }\end{array}$ & & & & \\
\hline $\begin{array}{l}5 \text { There is an eye-catching title and/ } \\
\text { or visual on the home page of this } \\
\text { course that will attract participants' } \\
\text { attention. }\end{array}$ & & & & \\
\hline
\end{tabular}




\begin{tabular}{|l|l|l|l|l|}
\hline QUESTIONS & $\begin{array}{l}3= \\
\text { strongly } \\
\text { agree }\end{array}$ & $\begin{array}{l}2= \\
\text { somewhat } \\
\text { agree }\end{array}$ & $\begin{array}{l}1= \\
\text { somewhat } \\
\text { disagree }\end{array}$ & $\begin{array}{l}0= \\
\text { strongly } \\
\text { disagree }\end{array}$ \\
\hline $\begin{array}{l}6 \text { This course provides valuable links } \\
\text { to other useful references, including } \\
\text { Websites. }\end{array}$ & & & & \\
\hline $\begin{array}{l}7 \text { The purpose of this course is } \\
\text { always clear to me. }\end{array}$ & & & & \\
\hline $\begin{array}{l}8 \text { The course has a help function } \\
\text { that I can use at any time. }\end{array}$ & & & & \\
\hline $\begin{array}{l}9 \text { This course is fun for participants } \\
\text { to explore. }\end{array}$ & & & & \\
\hline $\begin{array}{l}10 \text { The course information is } \\
\text { provided by credible sources. }\end{array}$ & & & & \\
\hline $\begin{array}{l}11 \text { The directions for using this } \\
\text { course are simple and clear. }\end{array}$ & & & & \\
\hline $\begin{array}{l}12 \text { I can control the pace of moving } \\
\text { through this course at all times, } \\
\text { including the use of the resources. }\end{array}$ & & & & \\
\hline $\begin{array}{l}13 \text { The content information included } \\
\text { in the course is interesting. }\end{array}$ & & & & \\
\hline $\begin{array}{l}14 \text { The information contained in this } \\
\text { course is current and up-to-date. }\end{array}$ & & & & \\
\hline $\begin{array}{l}15 \text { There is useful information on } \\
\text { each topic at the course resources. }\end{array}$ & & & & \\
\hline $\begin{array}{l}16 \text { The course resources are crisp } \\
\text { and clearly visible. }\end{array}$ & & & & \\
\hline $\begin{array}{l}17 \text { The variety of formats used in } \\
\text { all resources helps to maintain } \\
\text { attention. }\end{array}$ & & & & \\
\hline $\begin{array}{l}18 \text { The information in this course is } \\
\text { accurate and unbiased. }\end{array}$ & & & & \\
\hline $\begin{array}{l}19 \text { All the information at this } \\
\text { course is presented using clear and } \\
\text { consistent language and style. }\end{array}$ & & & & \\
\hline $\begin{array}{l}20 \text { All of the course resources are } \\
\text { active and fully functioning. }\end{array}$ & & & & \\
\hline
\end{tabular}




\begin{tabular}{|l|l|l|l|l|}
\hline QUESTIONS & $\begin{array}{l}3= \\
\text { strongly } \\
\text { agree }\end{array}$ & $\begin{array}{l}2= \\
\text { somewhat } \\
\text { agree }\end{array}$ & $\begin{array}{l}1= \\
\text { somewhat } \\
\text { disagree }\end{array}$ & $\begin{array}{l}0= \\
\text { strongly } \\
\text { disagree }\end{array}$ \\
\hline $\begin{array}{l}21 \text { This course has novel or } \\
\text { unique features that make it more } \\
\text { interesting for participants. }\end{array}$ & & & & \\
\hline $\begin{array}{l}22 \text { There is little or no unimportant } \\
\text { or redundant information at this } \\
\text { course. }\end{array}$ & & & & \\
\hline $\begin{array}{l}\text { 23 The course content is well- } \\
\text { written with no grammatical, } \\
\text { spelling, or other errors. }\end{array}$ & & & & \\
\hline $\begin{array}{l}24 \text { At all times, I can control what } \\
\text { information at the course I wish to } \\
\text { see. }\end{array}$ & & & & \\
\hline $\begin{array}{l}25 \text { There are unexpected surprises } \\
\text { at this course. }\end{array}$ & & & & \\
\hline $\begin{array}{l}26 \text { This course provides } \\
\text { opportunities for interactivity to } \\
\text { engage students. }\end{array}$ & & & & \\
\hline $\begin{array}{l}27 \text { This course provides the } \\
\text { appropriate amount of information } \\
\text { on the topic for a lesson or } \\
\text { assignment. }\end{array}$ & & & & \\
\hline $\begin{array}{l}28 \text { All resources and other } \\
\text { navigation mechanisms for moving } \\
\text { around at this Website work the way } \\
\text { they should. }\end{array}$ & & & & \\
\hline $\begin{array}{l}29 \text { The colors and/or background } \\
\text { patterns used in this course are } \\
\text { pleasing. }\end{array}$ & & & & \\
\hline $\begin{array}{l}30 \text { This course provides } \\
\text { opportunities to communicate } \\
\text { with its authors, participants, and } \\
\text { technical support. }\end{array}$ & & & & \\
\hline $\begin{array}{l}31 \text { No matter where I am in this } \\
\text { course, I can access any resources } \\
\text { and return to the course page or } \\
\text { exit. }\end{array}$ & & & & \\
\hline
\end{tabular}




\begin{tabular}{|l|l|l|l|l|}
\hline QUESTIONS & $\begin{array}{l}3= \\
\text { strongly } \\
\text { agree }\end{array}$ & $\begin{array}{l}2= \\
\text { somewhat } \\
\text { agree }\end{array}$ & $\begin{array}{l}1= \\
\text { somewhat } \\
\text { disagree }\end{array}$ & $\begin{array}{l}0= \\
\text { strongly } \\
\text { disagree }\end{array}$ \\
\hline $\begin{array}{l}\text { 32 There is enough amount of time } \\
\text { to learn how to use the resources. }\end{array}$ & & & & \\
\hline
\end{tabular}

Table 1 - Motivational Research Form - FPM

Source: Paixão, 2008; Blasca, 2012

The FPM is composed of 32 enunciations. Numerically, each statement is punctuated as follows: (3) strongly agree, (2) somewhat agree, (1) somewhat disagree and $(0)$ strongly disagree.

FPM's statements are grouped into four domains: "Stimulating", "Meaningful", "Organized" and "Easy to use". The "Stimulating" domain is grouped by the statements 1, 5, 9, 13, 17, 21, 25 and 29. The "Meaningful" domain by the statements 2, 6, 10, 14, 18, 22, 26 and 30. The domain "Organized" by the statements 3, 7, 11, 15, 19, 23, 27 and 31. The "Easy to use" domain by Enunciations $4,8,12,16,20,24,28$, and 32 .

After the score of each domain is performed individually, they are grouped according to the formula: $\mathrm{V}=\mathrm{E}+\mathrm{S}$; $\mathrm{XS}=\mathrm{O}+\mathrm{F}$. The $\mathrm{V}$ score is the sum of the "Stimulating" and "Meaningful" domains and reflects the Value dimension, that is, how valuable this training program is. The XS score is the sum of the "Organized" and "Easy to use" domains and reflects the expectation dimension for success. To finalize the score, the authors of WebMAC (Small and Amone, 1999) recommended the use of a Cartesian projection. The Abscissa (X-axis) is the score corresponding to the value dimension and the Ordinate (Y-axis) is the score corresponding to the Expectation dimension for Success. If the points or a large number of individual points are located within the area (Amazing Course!), it means that the training program is an "Impressive Course", evaluating it positively (Blasca, 2012).

In a second moment, another reading of the instrument is proposed, where some items pertaining to the principles of Information Design - communication, cognition, aesthetics and usability (Pena de Sá, 2016) - are identified. For this, the issues have been separated according to these items, and some fall into more than one category. However, other issues were not analyzed because they were specific to the context of the audiology or other resources of the portal, oblivious to the scope of this article. 


\section{Data Analysis}

The data collected by the questionnaires was transferred to a Microsoft Excel spreadsheet, where they were analyzed using descriptive statistics and frequency tables.

The questions that connect to the principles of the Information Design are also analyzed quantitatively and qualitatively.

\section{Evaluation of the Questionnaires}

\section{Motivational Research Form - FPM (Q2)}

This instrument aims to assess subjectively the motivational aspects of a training program in the fields: "Stimulating", "Meaningful", "Organized" and "Easy to use".

Table 2 presents the descriptive statistical analysis per domain evaluated by the participants in the FPM.

\begin{tabular}{|l|l|l|l|l|}
\hline Domain & Average & Minimum & Maximum & Sd \\
\hline Stimulating & 22,32 & 17 & 24 & 1,536 \\
\hline Meaningful & 21,97 & 16 & 24 & 2,213 \\
\hline Organized & 22,52 & 17 & 24 & 1,568 \\
\hline Easy to Use & 21,45 & 17 & 24 & 1,786 \\
\hline
\end{tabular}

Table 2 - Descriptive statistical analysis by domain evaluated by the participants in FPM

Sd= Standard deviation

According to the recommendation of the authors of WebMAC Professional (Small and Amone, 1999) and the other studies that used the FPM (Blasca, 2012; Piccolini and Maximino, 2014) the results are presented by the Cartesian projection (Figure 7), demonstrating the expectation for the success of the elaborate program. 
Alta Expectativa pelo Sucesso

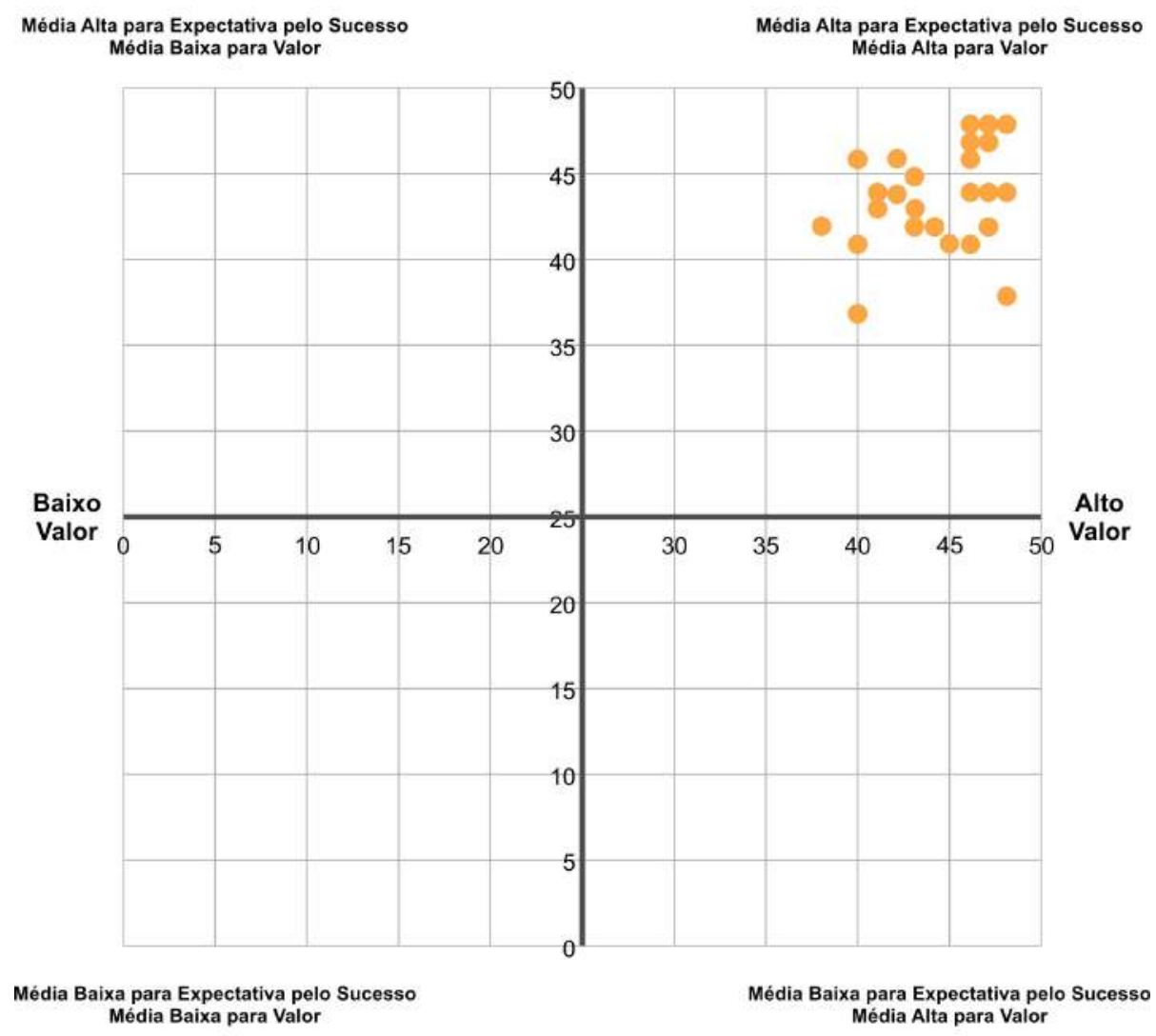

Baixa Expectativa pelo Sucesso

Figure 7- Classification of the training program of the FM System Portal

Evaluation through the principles of Information Design

17 questions were selected for this separate evaluation, at this time, according to analysis based on the principles of the Information Design. Some of the items presented here have been fitted in more than one principle, according to the analysis below.

1. Communication (Questions: 2, 5, 6, 9, 11, 19, 21), average 2,82

Questions pertaining to navigation components were evaluated, which are used for communicating with other parts of the portal, such as menu, homepage title, links or practical references, in addition, points out whether the course offered information of form and with simple, clear and interesting language

2. Cognition: (Questions: 1, 2, 3, 4, 5, 9, 12, 19, 20, 21, 24, 28, 29), average 2,76 
From this item emerged questions about the perception of audiovisual information, attraction and attention generated by the content, cognitive mechanisms of navigation (wayfinding), proximity and similarity, and form of presentation of information.

3. Aesthetics: (Questions 1,3, 5, 11, 29), average 2,88

Aspects related to layout, audiovisual information, grid, color pattern and typography that provide greater ease of perception have been evaluated.

4. Usability: (Questions 2, 3, 4, 6, 12, 20, 21, 24, 25, 28), average 2,67

This item relates to the analysis of the items for the available resources, guidance, and ease of navigation and portal interaction.

\section{DISCUSSION AND FINAL CONSIDERATIONS}

The development of a website for the training of professionals working in Brazilian Auditory Health Services, in the routine of adaptation and monitoring of the user of FM System, was a strategy adopted to disseminate the knowledge about the process of adaptation of this hearing aid, since SUS began to grant this technology assisted in 2013, without the indication of a protocol to be followed.

The development of the content for the FM System Portal privileged the aspects of the Information Design, based on the methodology of instructional design proposed by Filatro and Piconez (2004) and the infography, which collaborates in the transmission of extensive content and complexes in a more clear and didactic way (Fassina, Cavalcante and Andrade, 2009; Pessoa and Maia, 2012). In a preliminary study with health professionals, most participants prefer the infographic format to general textual summaries to report results of clinical studies in a variety of configurations (Turck et al., 2014).

The objective of this study was to evaluate the efficiency of the use of graphics for the transmission of information in the health area and it is part of an extensive data collection on the theme "FM System", which generated the portal. For this reason, the analyses demonstrated here sometimes exceed this barrier, evaluating items about the theoretical content and the usability of the system. Thus, the emphasis was given in the face of the results that refer to the aspects of the design, especially focused on the infography, which clarifies the use of the principles of the Design of the Information for the interpretation of the results along with the Motivational Research Form.

The evaluation of this website generated results that demonstrated high motivational satisfaction with the FM System Portal, presented by the Cartesian projection (Figure 4), where the participants considered it impressive, as in the study of Blasca et al. (2014), what points out how effective the use of infography 
for training of the use of the FM System for professionals.

The results also indicate that the "Organized" domain, according to the motivational aspects, and the principle of "aesthetics", pertaining to the principles of the Information Design, were the most punctuated by the participants, corroborating with studies that show the ease of reading that the infographic can provide (Fassina, Cavalcante and Andrade, 2009; Pessoa and Maia, 2012; Turck et al., 2014), in addition to the need to obey the precepts of design in the elaboration of such products (Bicen and Beheshti, 2017).

As for the motivational aspects and the principles of Information Design, respectively, the "easy-to-use" domain and the principle of "usability" have obtained the smallest media. These items refer to the ease of use, navigation, and items related to the general operation of the website. This deficiency occurred due to the lack of tools to design a more interactive and intuitive system. Rodrigues (2016) relates the Information Design to some features of Web Design, such as navigation systems that are user experience elements.

However, it is worth pointing out that the difference between the values attributed to each domain of the motivational aspects and the principle of the Information Design attributed by the notes of the survey participants did not have significant difference between them, so that all the values were considered high, revealing the efficiency and effectiveness of the strategy to provide theoretical content in the form of infographics. This success is confirmed through the improvements generated in the performance of the sample, through a good impact on the professional activities, after the access of the participants to the modules of the FM System Portal (Alves, 2016).

The interface between the areas of Audiology and Design contributed to the success of the training by searching for assertive content on the theme and graphics solutions suitable for its presentation, within the context to which it applies and targeted to the target audience. Lopes et al. (2012) propose intervention in the propositions of Andragógicas directives, based on methodologies of Information Design in design and education areas.

There is a point here for the need to use graphics resources based on the Information Design in training products for the health area for the professional motivation. Studies in Information Design in the elaboration of digital artifacts are necessary for the current context, where there are high flow and supply of information, especially in the digital universe of the Internet (Rodrigues, 2016).

Finally, it is suggested that the FM System Portal is continually updating, and modules are added to the training of student users' teachers, as well as initiatives for training of FM System users in school environment, so as in the family context or in other activities where it is necessary to use this auxiliary communication device. 


\section{REFERENCES}

Alessandrini, K. L. 1984. Pictures and adult learning. Instr Sci.v.13:63-77.

Alves, T. K. M. 2017. Portal Sistema FM: intercâmbio técnico científico entre profissionais que atuam com alunos usuários de Sistema FM. [dissertação]. Bauru (SP): Faculdade de Odontologia de Bauru da Universidade de São Paulo

American Academy of Audiology. 2011. Clinical practice guidelines: remote microphone hearing assistance technologies for children and youth from birth 21 years. <http:// audiologyweb.s3.amazonaws.com/migrated/HAT_Guidelines_Supplement_A. pdf_53996ef7758497.54419000.pdf>

Blasca, W. Q.; Ferrari, D. V. and Jacob, R. T. S. 2006. Dispositivos eletrônicos aplicados à surdez: conceitos básicos In: Flores K. G.; Lamônica D. A. C. and Bevilacqua M. C. O processo de comunicação: contribuição para a formação de professores na inclusão de indivíduos com necessidades educativas especiais: 197-213. São José dos Campos: Pulso Editorial.

Blasca, W. Q. 2012. Telessaúde: intercâmbio técnico científico entre centros de atendimento ao deficiente auditivo [tese]. Bauru (SP): Faculdade de Odontologia de Bauru, Universidade de São Paulo.

Brasil, 2015. Sistema de frequência devolve qualidade de ensino a pacientes com problemas auditivos. In: Blog da Saúde do Ministério da Saúde <http://www.blog.saude.gov. br/index.php/35439-sistema-de-frequencia-devolve-qualidade-de-ensino-a-pacientes-com-problemas-auditivos>

Brasil, 2013. Portaria n ${ }^{\circ} 1.274$, de 25 de junho de 2013. Inclui o Procedimento de Sistema de Frequência Modulada Pessoal (FM) na Tabela de Procedimentos, Medicamentos, Órteses, Próteses e Materiais Especiais (OPM) do Sistema Único de Saúde. <http:// bvsms.saude.gov.br/bvs/saudelegis/gm/2013/prt1274_25_06_2013.html>

Bicen, H. and Beheshti. M. 2017. The Pshychological Impact of Infographics in Education. In: BRAIN - Broad Research in Artificial Intelligence and Neuroscience, v.8, n.4:99-108.

Cairo, A. 2008. Infografía 2.0: visualización interactiva de información en prensa. Madrid: Alamut.

CAT - Comitê de Ajudas Técnicas. Tecnologia assistida - 2009. Disponível em: <http:// www.pessoacomdeficiencia.gov.br/app/sites/default/files/publicacoes/livro-tecnologia-assistiva.pdf >. Acesso em: 28 fev. 2017

Deficiência, viver sem limite: plano nacional dos direitos da pessoa com / Secretaria de Direitos Humanos da Presidência da República (SDH/PR) / Secretaria Nacional de Promoção dos Direitos da Pessoa com Deficiência (SNPD). Viver sem Limite - Plano Nacional dos Direitos da Pessoa com Deficiência: SDH-PR/SNPD; 2013. <http:// www.desenvolvimentosocial.sp.gov.br/a2sitebox/arquivos/documentos/633.pdf>

Domiciniano, Marcus Aurelius, Lopes. A condução da informação da linguagem científica ao infográfico [dissertação]. Bauru (SP): Faculdade de Arquitetura, Artes e Co- 
municação, Universidade Estadual Paulista.

Fassina, U., Cavalcante, A.L.B. and Andrade, R. C. 2009. Reflexões sobre a complementariedade imagem e texto, e o seu papel na criação da linguagem da infografia. In: Anais do $2^{\circ}$ Encontro Nacional dos Estudos da Imagem; Londrina, Brasil <http:// www.uel.br/eventos/eneimagem/anais/caderno_de_resumos_site.pdf>

Ferrarid. V.; Blasca, W. Q.; Bernardez-Braga, G. R. A. and Wen, C. L. 2010. Telessaúde: acesso à educação e assistência em audiologia. In: Bevilacqua, M. C.et al. Saúde Auditiva no Brasil: políticas, serviços e sistemas. 189-218. São José dos Campos: Pulso Editorial.

Filario, A. and Piconez, S. C. B. 2004. Design instrucional contextualizado: planejamento, elaboração e avaliação de materiais didáticos para educação a distância. <http:// www.abed.org.br/congresso2004/por/pdf/049-TC-B2.pdf.>

Guedes, D. M. P. 2017. Tradução e adaptação transcultural de materiais educativos: proposta metodonógica de validação no context da saúde. [dissertação]. Bauru (SP): Faculdade de Odontologia de Bauru da Universidade de São Paulo.

Jacob, R. T. S. et al. 2012. Sistema de frequência modulada em crianças com deficiência auditiva: avaliação dos resultados. Revista da Sociedade Brasileira de Fonoaudiologia v.17, n.4:417-421.

Jacob, R. T. S. and Queiroz-Zattoni, M. 2011. Sistemas de Frequência Modulada (FM). In: Bevilacqua, M. C. el al. Tratado de Audiologia. 727-741. São Paulo: Santos.

Lopes, M. T.; Coutinho, S.G. and Barbosa, N. C. P. 2012. Contribuições de metodologias de design para a prática pedagógica: apresentação de um esquema inicial. Revista Brasileira de Design da Informação. v.9, n.1:10-20.

Passos, R. and Moura, M. 2007. Design da Informação na hipermídia. Infodesign. v.4, n. $2: 20-28$

Paixão, M. P. 2008. Modelo de educação a distância em hanseníase voltado para a rede de detecção de casos e diagnóstico [tese]. São Paulo (SP): Faculdade de Medicina, Universidade de São Paulo.

Pena de Sá, R. 2016. Os princípios de design da informação e sua aplicação em projetos de websites de jornais: estudo de caso do website do jornal O Globo. [dissertação] Brasília (DF): Mestrado em Design - Universidade de Brasília.

Pessoa, A. R. and Maia, G. G. 2012. A infografia como recurso didático na Educação à Distância. Revista Temática. v.VIII, n.5.

Picolini, M. M. and Maximino, L. P. 2014. Programa de educação em síndromes genéticas: avaliação motivacional de um material educacional on line. Revista CEFAC. v.16, n.1:252-259.

Queiroz-Zanotti, M. 2012. Benefício do sistema de frequência modulada em crianças usuárias de aparelhos de amplificação sonora individual e implantes cocleares [dissertação]. São Paulo (SP): Faculdade de Medicina da Universidade de São Paulo.

Rodrigues, D. D. 2016. Ciência da Informação e Web Design: Interseções teóricas em busca de melhores práticas [dissertação]. Rio de Janeiro (RJ): Escola de Comunicação 
- Universidade Federal do Rio de Janeiro.

Samara, T. 2010. Elementos do design: Guia de estilo gráfico. Porto Alegre: Bookman.

Samara, T. 2011. Guia de tipografia: Manual prático para o uso de tipos no design gráfico. Porto Alegre: Bookman.

Small, R. V. and Arnone, M. P. 1999. Motivation mining: prospecting the web. The Book Report. v.18:42-4.

Turck, C. J. et al. 2014. A Preliminary Study of Health Care Professionals' Preferences for Infographics Versus Conventional Abstracts for Communicating the Results of Clinical Research. Journal of Continuing Education in the Health Professions. v.34, n.S1:S36-S38. 